\title{
Barriers to the use of dental services by children in Lebanon and association with parental perception of oral health care
}

Ingrid Karam, ${ }^{1}$ Miran A. Jaffa ${ }^{2}$ and Joseph Ghafari ${ }^{1}$

${ }^{1}$ Division of Orthodontics and Dentofacial Orthopedics, Department of Otorhinolaryngology, Head and Neck Surgery, American University of Beirut Medical Center, Beirut, Lebanon. ${ }^{2}$ Epidemiology and Population Health Department, Faculty of Health Sciences, American University of Beirut, Beirut, Lebanon. (Correspondence to: Miran Jaffa: ms148@aub.edu.lb).

\begin{abstract}
Background: Oral health is important to general health but use of dental services varies considerably, particularly for children.

Aims: We aimed to determine factors associated with parents' use of dental services for their children in Lebanon, and their perception of dental care relative to medical care.

Methods: A convenience sample of public and private schools in Beirut was selected between January and May 2013. Parents of children in grades 2-6 (aged 7-12 years) were invited to complete a questionnaire covering socioeconomic characteristics and use of dental services. Logistic regression analysis was used to assess the relationship between use of dental services, and parents' socioeconomic characteristics and awareness and perceptions of dental services.

Results: The parents of 316 children returned the questionnaire. Most children (72.8\%) had been taken to the dentist in the past year, mainly for emergency care. Most parents $(78.2 \%)$ considered dental care as important as or more important than medical care, and $89.9 \%$ were willing to contribute to dental insurance. Use of dental services was significantly associated with: older age of the parent (odds ratio, $\mathrm{OR}=1.04 ; 95 \%$ confidence interval, CI: 1.02-1.06); awareness of dental care centres offering affordable treatment ( $\mathrm{OR}=3.18 ; 95 \%$ CI: 1.52-6.68); and children being in private schools (OR $=2.00,95 \%$ CI: 1.08 3.95). It was negatively associated with $>4$ children in the family compared with 1 child (OR $=0.18$; 95\% CI: 0.04-0.81).
\end{abstract}

Conclusion: Barriers to dental care for children were mostly related to economic factors.

Keywords: dental care for children, oral health care, dental insurance, Lebanon

Citation: Karam I; Jaffa MA; Ghafari J. Barriers to the use of dental services by children in Lebanon and association with parental perception of oral health care. East Mediterr Health J. 2020;26(11):1420-1424. https://doi.org/10.26719/emhj.20.079

Received: 02/05/19; accepted: 03/11/19

Copyright (C) World Health Organization (WHO) 2020. Open Access. Some rights reserved. This work is available under the CC BY-NC-SA 3.0 IGO license (https://creativecommons.org/licenses/by-nc-sa/3.o/igo)

\section{Introduction}

Poor oral health, which is related to excessive sugar intake and low levels of fluoride exposure $(1,2)$, affects $60-90 \%$ of schoolchildren globally (3) and the most socially disadvantaged populations (4), particularly given the high cost of treatment in low- and middle-income countries $(5,6)$. The use of dental services has been widely investigated in relation to sociodemographic variables. Utilization is lower in younger people (21-35 years) and people of lower socioeconomic status (7). On the other hand, the use of dental services in children is greater when parents have a higher education $(4,7,8)$ and have a better perception about oral health, including preventive and comprehensive care rather than only emergency treatment (e.g. toothache) $(4,9)$. In addition, utilization of dental care is greater when third-party dental coverage is available - uninsured people are twice as likely to neglect dental care as insured people (10). Low utilization of dental services was associated with treatment expenses in Lebanon (11), where only about $20 \%$ of the population benefit from dental insurance through military and civil servant programmes (12).

In addition, oral health is globally the most common unmet health care need (13). This fact raises the question about people's perception of oral care in relation to medical care. Although a statistically significant association has been reported between perceived general and dental health (14), the relationship between such perception and use of dental services is not well known.

We hypothesized that the perception of the importance of oral care in relation to medical care may be associated with use of dental services, and that utilization among Lebanese schoolchildren would reflect the oral care perception of parents and related practices. Private and public schools are fairly equally distributed in Beirut $-52.8 \%$ and $47.2 \%$ of pupils attend private and public institutions, respectively (15). They therefore represent a good model for socioeconomic background.

The aims of our study were to: (i) identify the factors associated with access to dental care in schoolchildren from different socioeconomic backgrounds and with the barriers preventing parents from using needed dental services for their children; and (ii) assess parental perception of dental care in relation to medical care.

\section{Methods}

\section{Study design and sample}

This was a cross-sectional study of children in grades 2 to 6 (aged 7-12 years) attending five private and two public 
schools in Beirut that agreed to allow children and their parents to participate in the study. The sample was a convenience sample in the first phase (January-May 2013) of a multiphase study on the children's oral health. In this phase, the children were given a consent form and a questionnaire to take home to their parents for them to sign and complete within one week. Parents who returned the signed consent form and the completed questionnaire were included in the study.

Power analysis showed that with a sample size of 316 responses, an effect size of 0.07 (between a small (0.02) and the medium (0.15) effect size) and a probability level of 0.05 , the statistical power is 0.8 , with 20 predictors.

\section{Data collected}

The questionnaire included standard demographic and socioeconomic questions and questions on the use of dental services. It did not include any scale that required validation. We did a pilot study on a random sample of 10 parents to ensure that the questions were clear to the participants. We excluded these parents from the study to avoid introducing bias. The recorded categorical variables were:

- Outcome variable: use of dental services - parents had taken their children to the dentist in the past year (yes/no) and reasons for taking them to the dentist (routine check-up and prevention, emergency motivated by pain, or orthodontics).

- Sociodemographic characteristics - sex of the responding parent, marital status (married/separated/ divorced), respondent parent's educational level (read and write, primary school, middle and secondary school, college/university), number of children in the family $(1,2,3,4,>4)$.

- Socioeconomic characteristics: family monthly income $(<1, \geq 1$ million Lebanese pounds (US\$ $1=1500$ Lebanese pounds]), children's school (public or private), family medical/dental insurance (yes/no).

- Respondent parent's awareness of dental care centres offering affordable treatment (yes/no).

- Respondent parent's perception of their children's oral health (less/equally/more important than their general health).

- Respondent parent's willingness to use dental services more for their children if they were covered by or paid premiums towards dental insurance (yes/no).

\section{Statistical analysis}

We used simple and multivariable logistic regression analyses to evaluate the association between use of dental services and the independent variables. Variables that were statistically significant $(P<0.05)$ in the simple logistic regression analysis were entered in the multivariable analysis. Given that observations from the same school tend to be correlated, we used a logistic regression analysis with a cluster effect at the school level. This method incorporates within-school intracluster correlation in the computation of standard errors. Data are presented as unadjusted and adjusted odds ratios (OR) and 95\% confidence intervals (CI). Stata, version 12.1 was used for the analyses.

\section{Ethical considerations}

The multiphase study was approved by the Institutional Review Board of the American University of Beirut. All participating parents signed an informed consent form.

\section{Results}

The parents of 316 children in grades 2 to 6 (aged 7-12 years) returned the questionnaire and signed the informed consent form. Age was recorded for 273 (86.4\%) parents: mean age and standard deviation (SD) was 38.30 (SD 6.40) years, range 16-57 years. The mean age of the children was 9.5 (SD 1.5) years. The proportion of completed questionnaires was about the same for public $(n=151,47.8 \%)$ and private $(n=165,52.2 \%)$ schools.

Most parents $(n=230 ; 72.8 \%)$ had taken their children to the dentist at least once in the past year, $61.3 \%$ of whom $(n=141 / 230)$ had made more than one visit. The reasons for the visits were: decay and acute pain $(n=206 ; 89.6 \%)$, regular check-up ( $n=153 ; 66.5 \%)$ and appearance of teeth $(n=131 ; 57.0 \%)$. Most parents $(n=284 ; 89.9 \%)$ were willing to invest in dental health and increase their utilization of dental services if costs were covered by dental insurance. We found statistically significant associations between use of dental services and eight variables in the simple regression analysis (Table 1): respondent's age, respondent's educational level, number of children in family, monthly family income, school type, medical insurance, perception of oral and general health, and awareness of the presence of dental care centres. Sex $(P=0.481)$ and marital status $(P=0.705)$ were not significantly associated with use of dental services and were not included in the multivariable analysis. In the multivariable analysis, four of these variables remained significantly associated with use of dental services - use of dental services increased with the older age of the respondent parent, fewer children in the family (> 4 children was significant in the unadjusted and adjusted analysis), awareness of dental care centres offering affordable treatments, and children being in private schools (Table 1).

\section{Discussion}

Many of our results corroborate the findings of previous studies. For example, the most common reason for dental visits was emergency care (acute pain and decay) rather than preventive care and orthodontics (16), and use of dental services was associated with economic status, educational level of the parent, and monthly family income (4,7-17). However, our main results relate to the effect on behaviour of awareness of affordable dental centres and the perception that dental care is equally important as or more important than medical care. 


\begin{tabular}{|c|c|c|c|c|c|}
\hline Variable & Values & $\begin{array}{l}\text { Unadjusted OR } \\
(95 \% \mathrm{CI})\end{array}$ & $\boldsymbol{P}$ & $\begin{array}{l}\text { Adjusted OR }{ }^{a} \\
\quad(95 \% \mathrm{CI})\end{array}$ & $\mathbf{P}$ \\
\hline \multicolumn{6}{|c|}{ Mean (SD) } \\
\hline Respondents' age (years) & $38.30(6.40)$ & $1.04(1.02-1.07)$ & $<0.001$ & $1.04(1.02-1.06)$ & $<0.001$ \\
\hline \multicolumn{6}{|c|}{ No. $(\%)$} \\
\hline \multicolumn{6}{|l|}{ Educational level } \\
\hline Read and write/Primary (Ref) & $74(23.8)$ & & & & \\
\hline Intermediate/Secondary & $94(30.2)$ & $0.93(0.34-2.53)$ & 0.901 & $1.02(0.33-3.10)$ & 0.967 \\
\hline College/University & $143(46.0)$ & $1.86(1.14-3.03)$ & 0.013 & $1.32(0.70-2.47)$ & 0.385 \\
\hline \multicolumn{6}{|l|}{ Children in the family } \\
\hline 1 (Ref) & $12(3.8)$ & & & & \\
\hline 2 & $102(32.3)$ & $0.34(0.07-1.63)$ & 0.180 & $0.55(0.17-1.80)$ & 0.328 \\
\hline 3 & $113(35.8)$ & $0.22(0.03-1.31)$ & 0.097 & $0.33(0.08-1.28)$ & 0.111 \\
\hline 4 & $58(18.4)$ & $0.18(0.02-1.16)$ & 0.072 & $0.24(0.05-1.00)$ & 0.050 \\
\hline$>4$ & $31(9.8)$ & $0.18(0.03-0.85)$ & 0.031 & $0.18(0.04-0.81)$ & 0.025 \\
\hline \multicolumn{6}{|c|}{ Monthly family income (Lebanese pounds ${ }^{b}$ ) } \\
\hline$<1000000$ (Ref) & $134(44.8)$ & & & & \\
\hline$\geq 1000000$ & $165(55.2)$ & $2.28(1.42-3.66)$ & $<0.001$ & $1.63(0.89-2.98)$ & 0.108 \\
\hline \multicolumn{6}{|l|}{ School type } \\
\hline Public (Ref) & $151(47.8)$ & & & & \\
\hline Private & $165(52.2)$ & $2.69(1.71-4.23)$ & $<0.001$ & $2.00(1.08-3.95)$ & 0.027 \\
\hline \multicolumn{6}{|l|}{ Have medical insurance } \\
\hline No (Ref) & $100(33.0)$ & & & & \\
\hline Yes & $203(67.0)$ & $1.99(1.35-2.93)$ & $<0.001$ & $0.94(0.54-1.65)$ & 0.84 \\
\hline \multicolumn{6}{|c|}{ Perception of oral health compared with general health } \\
\hline Less important (Ref) & $52(17.4)$ & & & & \\
\hline As important/more important & $247(82.6)$ & $2.13(1.01-4.52)$ & 0.047 & $1.02(0.01-1.65)$ & 0.905 \\
\hline \multicolumn{6}{|c|}{ Awareness of dental care centres offering affordable services } \\
\hline No (Ref) & $157(52.9)$ & & & & \\
\hline Yes & $140(47.1)$ & $1.99(1.25-3.19)$ & 0.004 & $3.18(1.52-6.68)$ & 0.002 \\
\hline
\end{tabular}

OR: odds ratio; CI: confidence interval; SD: standard deviation; Ref: reference category.

${ }^{a}$ Adjusted for all other variables in the multivariable analysis.

${ }^{b} U S \$ 1=1500$ Lebanese pounds.

Percentages (\%) are computed out of the total responses for each question

The fact that almost twice as many of the parents who had medical insurance used dental services for their children compared with those without medical insurance shows that insurance coverage increases utilization, potentially improving oral health and preventive care visits. This trend has been shown in low-income Americans with a dramatic increase (from $33 \%$ to $80 \%$ ) in dental service utilization when they have medical insurance (18). Furthermore, most parents of children in both public and private schools $(89.8 \%)$ were willing to invest in dental health, which shows the importance of implementing dental insurance within the medical insurance programmes.

Health issues are concerned with life and death or quality of life. Most dental and many medical problems are not life-threatening but they can affect quality of life considerably. Yet, oral health care and general health care are considered independent entities. Why should a line be drawn between a headache and a toothache, whether mild or debilitating? The roots of a seemingly artificial split may lie in education (separate medical and dental schools) and insurance (separate for medical and dental needs) (19). Policy-makers should rethink this categorization and consider integration based on the principle that oral health is part of total health. The financial burdens of dental services may be addressed by giving greater coverage for preventive care and progressive copayment for different treatment options of more demanding procedures.

Our study has some limitations, mainly the potential response bias and the convenience nature of the sample (selection was based only on agreement of schools and parents to participate in the study). More research is warranted on perception and awareness of dental needs and care with a larger sample from different geographic areas. Such research should evaluate the psychological disposition to seek preventive dental care, and ways to encourage everyone to have regular check-ups. 
In conclusion, the use of dental services reflected the disparity in economic and educational levels of the parents. Even the poorer respondents would be prepared to share in the cost of dental insurance coverage, regardless of the presence or absence of medical insurance. This finding indicates that people perceive oral health as part of total health and suggests that the present system of separate coverage for medical and dental needs should be reconsidered.

Funding: None.

Competing interests: None declared.

\section{Recours aux services dentaires chez les enfants au Liban : obstacles et association avec la perception parentale des soins de santé bucco-dentaire}

\section{Résumé}

Contexte : La santé bucco-dentaire est importante pour la santé générale, mais le recours aux services dentaires varie considérablement, en particulier chez les enfants.

Objectifs : La présente étude visait à déterminer les facteurs associés au recours par les parents aux services dentaires nécessaires pour leurs enfants au Liban, et leur perception de ces soins par rapport aux soins médicaux.

Méthodes : Un échantillon de commodité d'écoles publiques et privées de Beyrouth a été sélectionné entre janvier et mai 2013. Les parents d'enfants scolarisés en école primaire (âgés de 7 à 12 ans) ont été invités à remplir un questionnaire dans lequel ils devaient indiquer les caractéristiques socio-économiques et le recours aux services dentaires. L'analyse de régression logistique a été utilisée pour évaluer la relation entre le recours aux services dentaires et les caractéristiques socio-économiques des parents ainsi que la sensibilisation à ces services et la perception de ceux-ci.

Résultats : Les parents de 316 enfants ont renvoyé le questionnaire. La plupart des enfants (72,8\%) avaient été emmenés chez le dentiste au cours de l'année précédente, principalement pour des soins d'urgence. La plupart des parents (78,2\%) considéraient que les soins dentaires étaient aussi importants ou plus importants que les soins médicaux, et $89,8 \%$ étaient disposés à contribuer à l'assurance dentaire. Le recours aux services dentaires était associé de maniere significative à : un âge plus avancé du parent (odds ratio, OR =1,04; intervalle de confiance à 95\%, IC: 1,02-1,06); la connaissance de centres de soins dentaires offrant un traitement abordable $(\mathrm{OR}=3,18$; IC à $95 \%: 1,52-6,68)$; et à la scolarisation des enfants dans des écoles privées ( $\mathrm{OR}=2,00$, IC à $95 \%: 1,08-3,95)$. Il y avait une corrélation négative dans les familles de plus de quatre enfants comparativement aux foyers à enfant unique (OR = 0,18; IC à $95 \%$ : 0,04-0,81).

Conclusion : Les obstacles aux soins dentaires pour les enfants étaient principalement liés à des facteurs économiques.

$$
\begin{aligned}
& \text { استخدام الأطفال لخدمات طب الأسنان في لبنان: العوائق التي تحول دون إدراك أهمية الرعاية الصحية للفم والعوامل }
\end{aligned}
$$

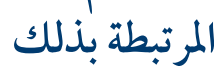

$$
\begin{aligned}
& \text { إنجريد كرم، مران جافا، جوزف غفري }
\end{aligned}
$$

الخلفية: تحظى صحة الفم بأهمية للصحة العامة، ولكن استخدام خدمات طب الأسنان يتفاوت تفاوتاً كبيراً، لا سيّما بالنسبة للأطفال.

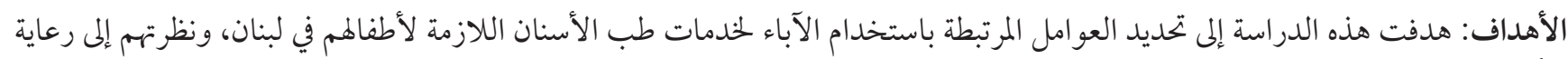
الأسنان بالنسبة للرعاية الطبية.

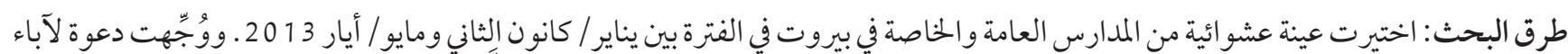

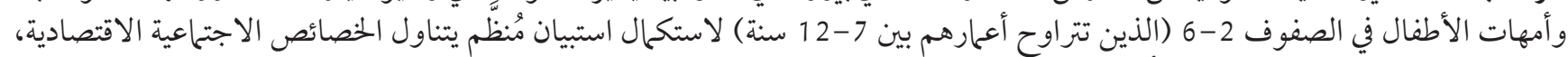

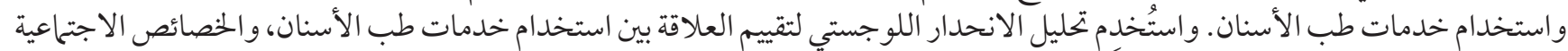

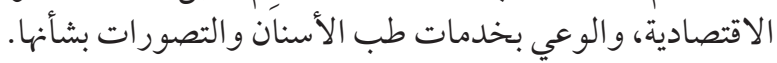

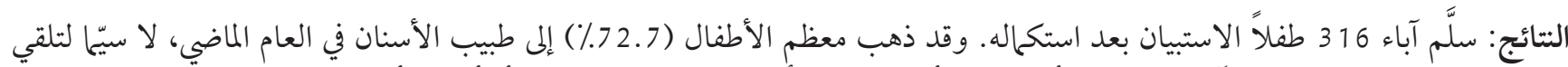

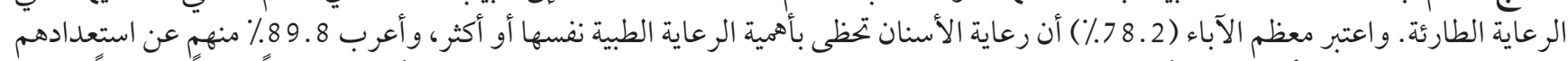

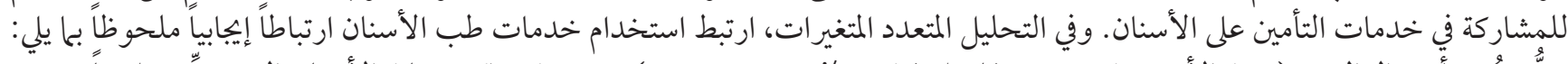

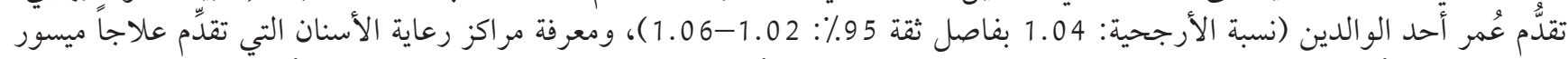

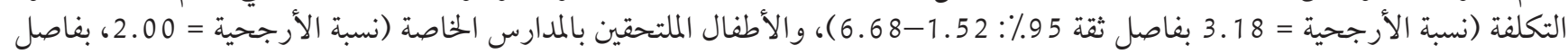




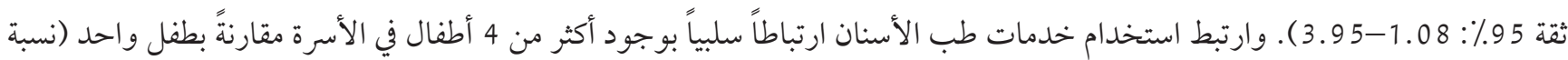

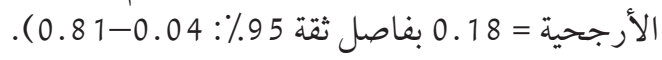
الاستناجات: ترتبط العوائق التي تعترض رعاية الأسنان للأطفال في الغالب بعوامل اقتهادية.

\section{References}

1. Inadequate or excess fluoride: a major public health concern. Geneva: World Health Organization; 2010 (https://apps.who.int/ iris/bitstream/handle/10665/329484/WHO-CED-PHE-EPE-19.4.5-eng.pdf?ua=1, accessed 8 May 2020).

2. Guideline: sugars intake for adults and children. Geneva: World Health Organization; 2015. (https://apps.who.int/iris/bitstream/ handle/10665/149782/9789241549028_eng.pdf?sequence=1\&isAllowed=y, accessed 8 May 2020).

3. Petersen PE, Ogawa H. Prevention of dental caries through the use of fluoride - the WHO approach. Community Dent Health. 2016;33(2):66-8. https://doi.org/10.1922/CDH_Peterseno3

4. Kelly SE, Binkley CJ, Neace WP, Gale BS. Barriers to care-seeking for children's oral health among low-income caregivers. Am J Public Health. 2005;95(8):1345-51. https://doi.org/10.2105/AJPH.2004.045286

5. Nunn JH. The burden of oral ill health for children. Arch Dis Child. 2006;91(3):251-3. https://doi.org/10.1136/adc.2005.077016

6. Shi L, Stevens GD. Disparities in access to care and satisfaction among US children: the roles of race/ethnicity and poverty status. Public Health Rep. 2005;120(4):433-8. https://doi.org/10.1177/003335490512000410

7. Wamala S, Merlo J, Bostrom G. Inequity in access to dental care services explains current socioeconomic disparities in oral health: the Swedish national surveys of public health 2004-2005. J Epidemiol Community Health. 2006;60(12):1027-33. https:// doi.org/10.1136/jech.2006.046896

8. Bell JF, Huebner CE, Reed SC. Oral health need and access to dental services: evidence from the National Survey of Children's Health, 2007. Matern Child Health J. 2012;16(Suppl 1):S27-34. https://doi.org/10.1007/s10995-012-0992-0

9. Cohen LA, Bonito AJ, Eicheldinger C, Manski RJ, Macek MD, Edwards RR, et al. Behavioral and socioeconomic correlates of dental problem experience and patterns of health care-seeking. J Am Dent Assoc. 2011;142(2):137-49. https://doi.org/10.14219/jada. archive.2011.0056

10. Roberts-Thomson KF, Slade GD. Factors associated with infrequent dental attendance in the Australian population. Aust Dent J. 2008; 53:358-62. https://doi.org/10.1111/j.1834-7819.2008.00079.x

11. Ammar W. Health system and reform in Lebanon. J Med Liban. 2001;5:72-4.

12. Ammar W, Awar M. What does the World Health Report 2000 bring to Lebanon? J Med Liban, 2001;49(3):123-5.

13. Petersen PE. Oral health. In: Heggenhougen K, Quah S, editors. International encyclopedia of public health. Cambridge (MA): Academic Press; 2008.

14. Richmond S, Chestnutt I, Shennan J, Brown R. The relationship of medical and dental factors to perceived general and dental health. Community Dent Oral Epidemiol. 2007;35(2):89-97. https://doi.org/10.1111/j.1600-0528.2007.00296.x

15. Yaacoub N, Badre L. Education in Lebanon. Beirut: Central Administration of Statistics; 2012 (http://www.cas.gov.lb/images/ PDFs/SIF/CAS_Education_In_Lebanon_SIF3.pdf, accessed 19 May 2020).

16. Petersen PE. World Health Organization global policy for improvement of oral health- World Health Assembly 2007. Int Dent J. 2008;58(3):115-21. https://doi.org/10.1111/j.1875-595x.2008.tboo185.x

17. Liu J, Probst JC, Martin AB, Wang JY, Salinas CF. Disparities in dental insurance coverage and dental care among us children: the national survey of children's health. Pediatr. 2007;119(Suppl 1):S12-21. https://doi.org/10.1542/peds.2006-2089D

18. Okada LM, Wan TT. Factors associated with increased dental care utilization in five urban, low-income areas. Am J Public Health. 1979;69(10):1001-9. https://doi.org/10.2105/ajph.69.10.1001

19. Ghafari JG. "Medically necessary" orthodontic care: challenges and applications. Semin Orthod. 2016; 22(3):167-76. https://doi. org/10.1053/j.sodo.2016.05.001 